\title{
PERAN GURU TK DALAM MENINGKATKAN KEMAMPUAN LITERASI BACA TULIS PADA ANAK USIA 4-5 TAHUN MASA PANDEMI COVID-19
}

\author{
Nila Fitria \\ Universitas Al Azhar Indonesia, Jakarta \\ Email korespondensi : Nilafitria0402@gmail.com
}

\begin{abstract}
Abstrak
Penelitian ini bertujuan menggambarkan peran guru dalam meningkatkan kemampuan literasi baca tulis pada masa pandemik covid-19 di wilayah Kota Tangerang yang mencakup rancangan kegiatan main yang disiapkan pada saat anak belajar dari rumah, media apa saja yang digunakan dalam meningkatkan kemampuan literasi baca tulis, metode apa yang digunakan guru dalam meningkatkan kemampuan literasi baca tulis serta, dan capaian perkembangan anak pada kemampuan literasi baca tulis. Metode penelitian menggunakan pendekatan kualitatif dengan Teknik pengumpulan data melalui wawancara dan dokumentasi. Adapun hasil penelitian ini menunjukkan 1) guru merancang kegiatan main pada perencanaan BDR berupa RPPM yang diinformasikan kepada orang tua baik melalui whatapps group, flyer, selembaran yang disediakan oleh Lembaga satuan PAUD, 2) Media yang digunakan dalam meningkatkan kemampuan literasi baca tulis anak usia dini bervariasi. Berupa video pembelajaran, video cerita, buku digital bermain keaksaraan, 3) Metode yang digunakan guru melalui metode bercerita, metode bernyanyi, metode project-based learning, metode tanya jawab, 4) Capaian perkembangan anak pada kemampuan literasi baca tulis dapat dilihat dengan ketertarikannya untuk membaca buku sendiri pada tahap membaca gambar. Penelitian ini dapat bermanfaat bagi guru untuk dapat mengembangkan beragam media dan metode yang dapat dilakukan pada pembelajaran daring. Selain itu orang tua, dapat mengoptimalkan kemampuan literasi baca tulis anak selama belajar dari rumah.
\end{abstract}

10.26418/pipt.2021.42

Kata kunci: baca tulis, covid-19, literasi, peran guru TK

\section{PENDAHULUAN}

Pandemi Covid 19 yang melanda hampir seluruh dunia memberikan dampak yang luar biasa ke dalam berbagai sektor kehidupan manusia. Tidak hanya dampak ekonomi yang bisa dirasakan langsung, namun dampak ke dunia pendidikan juga sangat signifikan. Dampak yang dirasakan di sektor pendidikan diantaranya perubahan paradigma metode pembelajaran, karena di masa pandemik ini tidak memungkinkan untuk bertatap muka secara langsung seperti yang dilakukan ketika sebelum pandemik hal ini dilaksanakan untuk mengurangi dampak penularan virus Covid 19 tersebut. Pembelajaran tanpa tatap muka dikenal juga sebagai pembelajaran jarak jauh atau belajar dari rumah (BDR), pelaksanaan BDR juga memaksa para pendidik untuk lebih dapat memahami penggunaan aplikasi digital pendukung pembelajaran terutama media live streaming seperti zoom, google meet dan lain sebagainya. Pada pembelajaran BDR, saat interaksi terjadi melalui media digital atau virtual, tentunya terdapat kendala-kendala dalam penyampaian materi pembelajaran. Hal ini berlaku hampir di setiap jenjang pendidikan dari TK hingga perguruan tinggi.

Kendala yang dihadapi untuk pembelajaran di TK atau anak usia dini, lebih beragam, terutama pada saat harus memenuhi kebutuhan orang tua dimana anak harus pandai membaca, menulis, dan berhitung. Guru sebagai pendidik tentunya mempunyai berbagai cara untuk mengembangkan kemampuan anak agar tumbuh dan berkembang dengan optimal. Berdasarkan Permendikbud No. 137 tahun 2014, terdapat tiga lingkup perkembangan bahasa yaitu memahami bahasa, mengungkapkan bahasa dan keaksaraan atau mengenal huruf. Kegiatan mengenal huruf 
merupakan suatu kesatuan kegiatan yang terpadu yang mencakup beberapa kegiatan seperti mengenali huruf dan kata-kata, menghubungkannya dengan bunyi, maknanya serta menarik kesimpulan mengenai maksud bacaan. Menurut Anderson cit. Dhieni (2013) "Membaca sebagai suatu proses untuk memahami makna suatu tulisan. Proses yang dialami dalam membaca adalah berupa penyajian kembali dan penafsiran suatu kegiatan dimulai dari mengenali huruf, kata, ungkapan, frase, kalimat, dan wacana serta menghubungkannya dengan bunyi dan maknanya (Primarni, 2021). Dapat disimpulkan bahwa kegiatan membaca terkait dengan (1) Pengenalan huruf atau aksara, (2) Bunyi dari huruf atau rangkaian huruf-huruf, (3) Makna atau maksud, dan (4) Pemahaman terhadap makna atau maksud berdasarkan konteks wacana. UNESCO mendefinisikan Literasi adalah kemampuan untuk mengidentifikasi, memahami, menafsirkan, membuat, berkomunikasi dan menghitung, menggunakan bahan cetak dan tertulis yang terkait dengan berbagai konteks. Literasi erat berhubungan dengan baca dan tulis. Pada proses pemahaman literasi baca tulis, anak membutuhkan tahapan dalam pengenalannya dan tentunya membutuhkan peran guru dalam mengoptimalkan.

Dalam Kamus Besar Bahasa Indonesia, guru diartikan sebagai orang yang pekerjaannya mengajar, yang ikut berperanserta dalam usaha pembentukan sumber daya manusia yang potensinya? Di bidang pembangunan, guru memiliki peran dalam proses pembelajaran anak usia dini. Melihat pentingnya peran guru dalam meningkatkan kemampuan literasi baca tulis pada anak usia dini, maka penelitian ini menggambarkan peran guru dalam meningkatkan kemampuan literasi baca tulis anak usia dini di taman kanakkanak pada masa pandemi covid 19. Adapun subfokus pada penelitian ini mencakup 1) Bagaimana bentuk rancangan yang disiapkan guru dalam meningkatkan kemampuan literasi baca tulis anak usia 4-5 tahun? 2) Bagaimana media yang digunakan guru dalam meningkatkan kemampuan literasi baca tulis anak usia 4-5 tahun? 3) Bagaimana metode yang digunakan guru dalam meningkatkan kemampuan literasi baca tulis anak usia 4-5 tahun? 4) Capaian perkembangan apa yang dikembangkan pada kemampuan literasi baca tulis anak usia 4-5 tahun? Tujuan penelitian ini dapat menggambarkan peran guru dalam meningkatkan kemampuan literasi baca tulis anak usia 4-5 tahun selama pandemi covid-19. Dengan demikian, penelitian ini diharapkan bermanfaat bagi guru lainnya dalam merancang kegiatan main yang dapat dilakukan belajar dari rumah. Selain itu penelitian ini bermanfaat bagi orang tua dalam rangka menumbuhkembangkan kemampuan literasi baca tulis anak usia 4-5 tahun.

\section{METODOLOGI}

\section{Jenis Penelitian}

Penelitian yang digunakan adalah penelitian kualitatif dimana penelitian ini menurut Cresswell (2008) mendefinisikan metode penelitian kualitatif sebagai suatu pendekatan atau penelusuran untuk mengeksplorasi dan memahami suatu gejala sentral. Untuk mengerti gejala sentral tersebut, Peserta penelitian atau partisipan dengan mengajukan pertanyaan yang umum dan agak luas. Informasi dikumpulkan berupa kata maupun teks. Kumpulan informasi tersebut kemudian dianalisis. Hasil analisis kemudian dijabarkan dengan penelitian-penelitian ilmuwan lain yang dibuat sebelumnya. Hasil akhir penelitian kualitatif dituangkan dalam bentuk laporan.

Jenis penelitian ini merupakan penelitian deskriptif yang bertujuan untuk meneliti dan menemukan informasi sebanyak banyaknya dari suatu fenomena. Penelitian ini mengungkapkan data-data yang berkaitan dengan peran guru dalam Meningkatkan kemampuan literasi baca tulis.

Lokasi dan Waktu Penelitian 
Penelitian ini dilaksanakan pada Taman Kanak-Kanak di wilayah Jabodetabek dengan subfokus rancangan pembelajaran, metode, media, dan capaian pembelajaran pada kemampuan literasi baca tulis anak usia 4-5 tahun. Penelitian ini dilakukan pada guru TK Islam Al Azhar Pasar Minggu- Jakarta, TK Islam An-Nash - Jakarta, TK Raudlatul Azhar - Tangerang, TK Muhammadiyah Limau- Jakarta, dan TK Nahwannur-Depok. Adapun waktu penelitian dilaksanakan pada bulan JuniJuli 2021.

\section{Data dan Sumber Data}

Sumber data dalam penelitian ini adalah pihak-pihak yang dapat memberikan informasi mendalam tentang peran guru dalam meningkatkan kemampuan literasi baca tulis anak usia 4-5 tahun, yaitu guru TK yang menjadi subyek penelitian.

\section{Metode dan Penentuan Subyek Penelitian}

Penelitian ini dilakukan di wilayah Jakarta, Tangerang, dan Depok sebagai subyek penelitian, yaitu TK Islam Al Azhar Pasar Minggu-Jakarta, TK Islam An-Nash-Jakarta, TK Raudlatul AzharTangerang, TK Muhammadiyah LimauJakarta, dan TK Nahwannur-Depok. Pemilihan subyek penelitian dengan mempertimbangkan keragaman karakteristik sekolah baik dari kelengkapan sarana dan prasarana, latar belakang anak, status akreditasi sekolah, dan kualitas guru. Tentunya hal tersebut dilakukan untuk memperoleh gambaran yang komprehensif dan representatif tentang peran guru dalam meningkatkan kemampuan literasi baca-tulis pada anak usia 4-5 tahun.

\section{Metode Pengumpulan Data}

Metode pengumpulan data menurut Sugiyono (2017) cara atau teknik pengumpulan data dapat dilakukan dengan: interview (wawancara), kuesioner (angket), observasi (pengamatan), dan gabungan ketiganya. Oleh karena itu maka teknik pengumpulan data yang digunakan dalam penelitian ini adalah sebagai berikut:

1. Pengamatan (Observasi)

Sugiyono (2017) menjelaskan observasi dilakukan dengan melihat langsung di lapangan. Metode observasi digunakan dalam penelitian yaitu mengamati dan mencatat anak langsung melakukan kegiatan main literasi baca tulis. Pada masa pandemi covid-19, pembelajaran yang dilakukan Belajar Dari Rumah (BDR) maka hasil pengamatan dilakukan secara daring.

2. Metode Dokumentasi

Metode dokumentasi dilakukan untuk mengumpulkan dokumen berupa fotofoto kegiatan main literasi baca tulis, rencana pembelajaran daring, dan capaian pembelajaran yang digunakan pada kegiatan pembelajaran.

3. Wawancara

Menurut Sugiyono (2017) wawancara digunakan sebagai Teknik pengumpulan data apabila peneliti ingin melaksanakan studi pendahuluan untuk mengetahui halhal dari responden yang lebih mendalam dan jumlah dari responden sedikit. Pada penelitian ini wawancara dilakukan kepada guru TK di wilayah Jakarta, Depok, dan Tangerang.

\section{Metode Analisis Data}

Teknik analisis data yang digunakan pada penelitian ini adalah analisis data model Miles \& Huberman. Miles \& Huberman cit. Sugiyono (2011) mengemukakan bahwa aktivitas dalam analisis data kualitatif dilakukan secara interaktif dan berlangsung secara terus menerus sampai tuntas, sehingga datanya sudah jenuh. Aktivitas dalam analisis data yaitu data reduction, data display dan conclusion drawing/verification.

1. Reduksi Data

Menurut Sugiyono (2016) reduksi data adalah merangkum, memilih hal-hal yang pokok, memfokuskan pada hal-hal yang penting dicari tema dan polanya. Data yang direduksi akan memberikan 
gambaran yang jelas dan mempermudah peneliti untuk mengumpulkan data terkait kemampuan literasi baca tulis anak usia dini.

2. Penyajian Data

Penyajian data menurut Miles \& Huberman cit. Sugiyono (2016) bahwa penyajian data bisa dilakukan dalam bentuk uraian singkat, bagan, hubungan antara kategori, flowchart, dan sejenisnya. Bentuk penyajian data dalam penelitian ini adalah narasi teks. Data yang diperoleh dari wawancara dan dokumentasi dianalisis dengan teori yang relevan agar dapat menggambarkan peran guru dalam meningkatkan kemampuan literasi baca tulis anak.

3. Kesimpulan

Data yang telah didapatkan dirangkum dan diarahkan pada kesimpulan untuk menjawab masalah yang telah dikemukakan peneliti terkait peran guru dalam meningkatkan kemampuan literasi baca tulis anak usia dini.

\section{HASIL DAN PEMBAHASAN}

\section{Rancangan Kegiatan Pembelajaran Literasi Baca Tulis}

Berdasarkan hasil penelitian, guru TK yang terdapat di wilayah Jakarta, Depok, dan Tangerang dengan status akreditasi Lembaga TK terdapat, 4 lembaga TK dengan status akreditasi A, 1 lembaga TK dengan status $\mathrm{B}$, dan 1 lembaga TK dengan status belum akreditasi. Guru TK merancang kegiatan pembelajaran selama pandemi covid-19. Bentuk perencanaan yang dibuat oleh guru TK dalam bentuk Rencana Perencanaan Pembelajaran Minguan (RPPM). Hal ini sejalan dengan Peraturan Menteri Pendidikan Nasional RI No. 16 tahun 2007 tentang Standar Kualifikasi Akademik dan Kompetensi Guru pada Standar Kompetensi Guru PAUD/TK/RA khususnya Kompetensi Pedagogik dimana guru mampu mengembangkan kurikulum yang terkait dengan bidang pengembangan yang diampu terkait kompetensi menyusun perencanaan semester, mingguan, dan harian dalam berbagai kegiatan pengembangan di TK/PAUD.

Perencanaan yang dibuat selama pandemi covid-19 dalam bentuk Rencana Perencanaan Pembelajaran Mingguan (RPPM) yang disampaikan kepada orang tua melalui whatapps group setiap hari, menginformasikan kepada orang tua melalui pertemuan orang tua secara daring (parents meet), dan pertemuan antara guru dan orang tua setiap awal tema untuk mensosialisasikan kegiatan dan tujuan tema secara daring. Orang tua dapat memilih kegiatan mana yang akan dimainkan bersama anaknya dan bilamana anak tidak tertarik dengan tema atau kegiatan yang dirancang guru, maka orang tua dapat mengganti dengan tema dan kegiatan main yang lain. Dalam hal ini peran guru dalam proses pembelajaran menurut Gage \& Berliner cit. Suyono \& Hariyanto (2014) melihat ada tiga fungsi utama guru dalam pembelajaran yaitu sebagai perencana (planner), pelaksana dan pengelola (organizer), dan penilai (evaluator).

\section{Media pada Kemampuan Literasi Baca- Tulis pada Anak Usia Dini}

Media menurut Arsyad (2002) adalah semua bentuk perantara yang digunakan oleh manusia untuk menyampaikan atau menyebar ide, gagasan atau pendapat, sehingga ide, gagasan, atau pendapat yang dikemukakan itu sampai kepada penerimaan yang dituju. Peran guru dalam memanfaatkan media untuk meningkatkan kemampuan literasi baca -tulis, menurut Rusman (2016) diklasifikasikan 1) Guru sebagai demonstrator, dimana guru memperagakan media, bahan, dan materi yang akan diajarkan kepada anak karena akan menentukan hasil belajar yang akan dicapai 2) Guru sebagai pengelola kelas, guru mampu melakukan penanganan di kelas karena kelas merupakan lingkungan yang perlu diorganisasi 3) Guru sebagai mediator dan fasilitator, guru memiliki pengetahuan dan pemahaman yang cukup untuk media pendidikan, karena media 
merupakan alat komunikasi guna mengefektifkan proses belajar mengajar 4) Guru sebagai evaluator, guru melakukan penilaian untuk mengetahui apakah tujuan yang dirumuskan tercapai atau tidak. Dalam hal penggunaan media, peran guru sebagai mediator, dimana pada kegiatan main guru menggunakan media untuk mencapai tujuan pembelajaran. Pada kegiatan main literasi baca-tulis, guru TK menggunakan kartu huruf, kartu gambar, buku cerita, video cerita, video, pohon huruf, dadu huruf, music, tepung, dan aplikasi quizizz selama BDR. Keragaman media digunakan untuk peningkatan kemampuan literasi baca tulis sesuai dengan tahapan perkembangannya. Hal tersebut dapat dilihat pada anak usia 4-5 tahun dimana pada tahapan menulis menurut Brewer cit. Widyastuti (2017) anak mampu menulis secara random letter stage (menulis random) ditandai dengan menggunakan huruf untuk menulis permulaan akan tetapi bentuk dari huruf tersebut masih sering terbalik dan acak penempatannya. Sehingga kartu huruf, dadu huruf, dan pohon huruf dapat digunakan untuk meningkatkan kemampuan menulis pada anak. Pada tahap selanjutnya anak sudah dapat menulis namanya (letter name writing) dimana anak menghubungkan tulisan dengan ejaannya melalui media kartu gambar, buku cerita, dan bermain tepung anak meningkatkan kemampuan menulis.

Buku cerita merupakan salah satu media yang digunakan guru dalam meningkatkan kemampuan membaca. Hal tersebut sejalan dengan Steinberg cit. Susanto (2011) bahwa tahapan membaca anak usia 4-5 tahun ditandai dengan tahap membaca gambar dimana anak sudah bisa memandang dirinya sebagai pembaca, dan mulai melibatkan diri dalam kegiatan membaca, pura-pura membaca buku cerita, memberi makna gambar, membaca buku dengan menggunakan Bahasa buku walaupun tidak cocok dengan tulisannya. Selain buku cerita, TK An Nash membagikan link buku digital Sirah Nabi kepada orang tua guna meningkatkan literasi baca tulis. Pada tahapan pengenalan bacaan anak menggunakan tiga system Bahasa, seperti fonem (bunyi huruf), semantik (arti kata), sintaksis (aturan kata) secara bersama-sama. Anak mulai mengenal tanda-tanda yang ada pada benda-benda.

\section{Metode pada Kemampuan Literasi Baca Tulis pada Anak Usia Dini}

Selain media, tentunya guru menggunakan metode pembelajaran guna meningkatkan kemampuan literasi baca tulis pada anak usia 45 tahun. Guru TK menggunakan metode bercerita, bernyanyi, metode tanya jawab, metode demonstrasi, metode proyek sebagai metode yang diterapkan dalam meningkatkan kemampuan literasi baca tulis anak selama BDR. Metode bercerita menurut Musfiroh cit. Nugroho (2018) digunakan sebagai upaya untuk menanamkan suatu karakter yang baik dalam menstimulasi enam aspek perkembangan anak, diantaranya adalah perkembangan moral, bahasa, kognitif, sosial emosional, motorik, dan seni. Melalui metode bercerita dengan buku cerita, anak tidak saja melihat tulisan yang menstimulasi anak untuk membaca tetapi juga menstimulasi anak untuk menirukan tulisan yang ada di dalam buku cerita.

Pada masa pandemi covid-19 ini, metode proyek dapat meningkatkan kemampuan literasi baca tulis dimana metode proyek menurut Moeslichatoen (2004) menjelaskan bahwa metode proyek merupakan salah satu cara pemberian pengalaman belajar dengan menghadapkan anak dengan persoalan seharihari yang harus dipecahkan secara berkelompok. Metode proyek dapat pula dilakukan secara individu, dalam rangka meningkatkan literasi baca tulis anak membuat proyek sederhana seperti membuat minuman kesukaan bersama orang tua di rumah. Anak dapat menuliskan alat dan bahan yang dibutuhkan kemudian menceritakan proses pembuatan minuman kesukaan. Salah satu kegiatan yang dilakukan selama BDR oleh guru TK.

Menurut Muhibinsyah metode demonstrasi adalah metode mengajar dengan 
memperagakan barang, kejadian, aturan, dan urutan, melakukan suatu kegiatan baik secara langsung maupun menggunakan media pengajaran yang relevan. Metode demonstrasi yang disiapkan oleh guru dalam bentuk video pembelajaran dapat meningkatkan literasi baca tulis di masa pandemi covid 19. Pada kegiatan main literasi baca tulis guru memperagakan menyusun huruf sesuai dengan kartu gambar yang didapat oleh anak. Hal tersebut tidak hanya meningkatkan kemampuan literasi baca tulis pada anak tetapi juga meningkatkan rasa ingin tahu anak.

\section{Capaian Perkembangan Literasi Baca Tulis pada Anak Usia 4-5 tahun}

Berdasarkan hasil penelitian yang diperoleh dari wawancara, capaian perkembangan anak dalam kemampuan literasi baca tulis sebagaimana yang dijelaskan dalam Peraturan Menteri No. 146 tahun 2014 tentang Kurikulum 2013 Pendidikan Anak Usia Dini dalam kompetensi dasar. Kompetensi dasar merupakan tingkat kemampuan dalam konteks muatan pembelajaran, tema pembelajaran, dan pengalaman belajar yang mengacu pada Kompetensi Inti (Kementerian Pendidikan dan Kebudayaan, 2015). Kompetensi Dasar terkait pada capaian perkembangan anak mencakup kompetensi dasar 3.10, 4.10, 3.11, 4.11, 3.12, 4.12. Guru menyiapkan kegiatan main seperti menirukan bentuk huruf dengan tepung, biji-bijian, batu, kancing, dan dedaunan, bermain kartu huruf, bermain kartu baca gambar, menyusun huruf dengan media yang disediakan, bercerita tentang proses membuat suatu proyek dan membuat jurnal. Tentunya mencapai perkembangan selama belajar dari rumah (BDR) memperhatikan prinsip dasar pengembangan dan implementasi literasi baca tulis yaitu (Kementerian Pendidikan dan Kebudayaan, 2017), 1) Prinsip keutuhan dan kemenyeluruhan (holistic), bahwa literasi baca tulis dikembangkan dan diimplementasikan secara holistic, terkait dengan aspek lainnya 2) Prinsip Keterpaduan (terintegrasi) dimana literasi baca tulis dikembangkan dan diimplementasikan dengan memadukan secara sistematis, menghubungkan dan merangkaikan secara harmonis dan melekatkan literasi baca tulis searah sinergis. 3) Prinsip keberlanjutan, literasi baca tulis dikembangkan dan diimplementasikan secara berkesinambungan, dinamis terus menerus, dan berlanjut dari waktu ke waktu 4) Prinsip Kontekstualitas, dimana kebijakan, strategi, program, dan kegiatan literasi baca tulis dikembangkan dan diimplementasikan dengan mendasarkan dan mempertimbangkan konteks geografis, demografis, sosial, dan kultural yang ada di Indonesia 5) Prinsip Responsif Kearifan Lokal, literasi baca tulis tidak berada di ruang vakum sosial dan budaya serta tidak bisa dikembangkan dan diimplementasikan dengan mengabaikan, lebih-lebih meniadakan lokalitas sosial dan budaya. Literasi baca tulis juga bermakna praktik dan hubungan sosial yang terkait dengan pengetahuan, Bahasa, dan budaya (UNESCO, 2003). Dalam hal ini guru berperan sebagai evaluator, dimana guru melakukan penilaian untuk mengetahui apakah mencapai tujuan pembelajaran.

\section{KESIMPULAN}

Berdasarkan hasil dan pembahasan penelitian, maka dapat disimpulkan bahwa peran guru dalam meningkatkan literasi baca tulis pada masa pandemi covid-19 sebagai berikut:

\section{Rancangan Kegiatan Pembelajaran Literasi Baca Tulis}

Tugas utama guru dalam pembelajaran yaitu sebagai perencana (planner) merancang kegiatan pembelajaran literasi baca tulis sesuai dengan tahapan perkembangan anak. Hal tersebut memperhatikan tahapan baca dan tahapan menulis anak.

\section{Media pada Kemampuan Literasi Baca- Tulis pada Anak Usia Dini}

Media sebagai alat yang digunakan guru dalam meningkatkan kemampuan literasi baca tulis sangat beragam. Guru TK menggunakan 
kartu huruf, kartu gambar, buku cerita, video cerita, video, pohon huruf, dadu huruf, music, tepung, dan aplikasi quizizz selama BDR. Hal ini menunjukkan peran guru sebagai mediator, dimana pada kegiatan main guru menggunakan media untuk mencapai tujuan pembelajaran.

\section{Metode pada Kemampuan Literasi Baca Tulis pada Anak Usia Dini}

Metode yang digunakan guru TK yaitu metode bercerita, bernyanyi, metode tanya jawab, metode demonstrasi, metode proyek sebagai metode yang diterapkan dalam meningkatkan kemampuan literasi baca tulis anak selama BDR.

\section{Capaian Perkembangan Literasi Baca} Tulis pada Anak Usia 4-5 tahun

Kompetensi Dasar terkait pada capaian perkembangan anak mencakup kompetensi dasar 3.10, 4.10, 3.11, 4.11, 3.12 , 4.12. Guru menyiapkan kegiatan main seperti menirukan bentuk huruf dengan tepung, biji-bijian, batu, kancing, dan dedaunan, bermain kartu huruf, bermain kartu baca gambar, menyusun huruf dengan media yang disediakan, bercerita tentang proses membuat suatu proyek dan menjurnal. Dalam hal ini guru berperan sebagai evaluator, guru melakukan penilaian untuk mengetahui apakah tujuan yang dirumuskan tercapai atau tidak.

\section{REKOMENDASI}

1. Bagi Guru Pendidikan Anak Usia Dini Sebaiknya guru PAUD berperan juga sebagai motivator dimana ketika anak Belajar Dari Rumah (BDR) diberikan motivasi untuk melakukan kegiatan main yang menyenangkan serta dapat memanfaatkan media dan bahan di sekitar rumahnya. Sehingga rasa ingin tahu anak semakin besar untuk terus belajar dan belajar menjadi bermakna buat anak.

2. Bagi Peneliti selanjutnya
Penelitian ini diharapkan dapat menjadi referensi dimana peran guru dalam meningkatkan kemampuan literasi baca tulis anak selama pandemi covid19.

\section{DAFTAR PUSTAKA}

Arsyad, Azhar. (2002). Media Pembelajaran. Jakarta: PT. Raja Grafindo Persada.

Cresswell. (2008). Reseach Design. Yogyakarta: Pustaka Belajar diterjemahkan oleh Achmad Fawaid.

Dhieni, N. (2013) Metode Pengembangan Bahasa (1st ed.). Tangerang: Universitas Terbuka Jakarta

Kementerian Pendidikan dan Kebudayaan. (2014). Peraturan Menteri No. 146 tahun 2014 tentang Kurikulum PAUD. Jakarta: Kementerian Pendidikan dan Kebudayaan.

Kementerian Pendidikan dan Kebudayaan. (2015). Peraturan Pemerintah No. 13 tahun 2015 tentang Kurikulum PAUD. Jakarta: Kementerian Pendidikan dan Kebudayaan.

Kementerian Pendidikan dan Kebudayaan. (2017). Gerakan Literasi Nasional. Jakarta: Kementerian Pendidikan dan Kebudayaan.

Moeslichatoen. (2004). Metode Pengajaran di Taman Kanak - Kanak. Jakarta: PT Rineka Cipta.

Nugroho, Yekti. (2018). Pembelajaran Pendidikan Agama Islam yang Menyenangkan dengan Mendongeng. Jurnal eL-Tarbawi. 11 (1).

Primarni, Amie. (2021). Penguatan Literasi Alam Kampung Ilmu Purwakarta. ElMujtama: Jurnal Pengabdian Masyarakat, 1 (1).

Rusman. (2016). Model-Model Pembelajaran mengembangkan profesionalisme guru. Jakarta: Raja Grafindo Persada. Hal. 6264. 
Sugiyono. (2011). Metode Penelitian Kuantitatif Kualitatif dan $R \& D$. Bandung: Alfabeta.

Sugiyono. (2016). Metode Penelitian Kuantitatif, Kualitatif, dan $R \& D$. Bandung: Alfabeta.

Sugiyono. (2017). Metode Penelitian Kuantitatif, Kualitatif, dan $R \& D$. Bandung: Alfabeta.

Susanto, Ahmad. (2011). Perkembangan Anak Usia Dini. Jakarta: Kencana Prenada Media Group.
Suyono \& Hariyanto. (2014). Belajar dan Pembelajaran Teori dan Konsep Dasar. Bandung: Remaja Rosdakarya.

UNESCO. (2003). The Prague Declaration. "Towards an Information Literate Society.

Widyastuti, Ana. (2017). Analisis Tahapan Menulis dan Stimulasi Anak Kelompok B-1 di TK Islam As Saadah Limo Depok. AWLADY: Jurnal Pendidikan Anak. 3 (2). 